\title{
Chapter 10 \\ (Im)mobility Patterns among Polish \\ Unemployed Migrants in Iceland \\ Navigating Different Welfare Regimes
}

\author{
Anna Wojtyńska and Unnur Dís Skaptadóttir
}

\subsection{Introduction}

In the autumn of 2008, Iceland was hit by a severe financial crisis that lead to a period of economic recession. The construction industry was one of the first sectors to be seriously affected, with many bankrupt companies and extensive layoffs. At the time, foreign citizens constituted $37 \%$ of the total number of workers in this sector, the majority coming from Poland (Statistics Iceland n.d.-a). The contraction of the economy resulted in an outflow of foreign workers from the country; however, it was not as extensive as commonly anticipated at the time (Eydal and Ottósdóttir 2009; Garðarsdóttir 2012). Firstly, the demand for foreign workers did not disappear with the financial crisis, because some sectors had become dependent on employees from abroad. Secondly, some migrants, despite losing their jobs, decided to continue living in Iceland. The unemployment rates among foreign citizens jumped from $1.3 \%$ at the end of July 2008 to $12.4 \%$ at the beginning of 2009. At this time, the unemployment rate among Polish citizens was as high as $18 \%$, peaking in March 2011, when it reached 23.6\% (Directorate of Labour n.d.).

In this chapter, we seek to answer the question of why so many unemployed Poles decided to stay and even bring their families to join them in Iceland, despite stagnation in the economy and the scarcity of available jobs. Based on interviews with unemployed Polish migrants, we examine how they negotiated and adapted to the social risks and changing circumstances encountered in the countries of emigration and immigration, as well as the way they navigated the available 'resource environments' (Levitt et al. 2017) emerging in conjunction with the different welfare regimes. We particularly examine the European Union (EU) regulations for social-security protection vis-à-vis national welfare-protection policies regarding

\footnotetext{
A. Wojtyńska $(\bowtie) \cdot$ U. D. Skaptadóttir

Faculty of Sociology, Anthropology and Folkloristics, University of Iceland,

Reykjavik, Iceland

e-mail: annawo@hi.is; unnurd@hi.is
} 
unemployment in Iceland and Poland and their possible ramifications for the mobility and (im)mobility of foreign workers in Iceland. Furthermore, we highlight some problematic interactions between the internationalisation of the labour market and concomitant transnational livelihoods, EU social policy and the welfare-assistance environment of member states. In so doing, we apply a critical approach to the commonly assumed high flexibility and geographical mobility of migrant workers, which tends to overlook counterfactors that influence different forms of staying put.

\subsection{Intra-European Labour Mobility}

The mobility of people, including the free movement of labour, constitutes one of the fundamental rights of EU (and EEA) citizens. It comprises one of the four pillars of the EU internal market, along with the free movement of goods, services and capital. The strong emphasis on unrestricted geographical mobility present in current EU policy reflects dominant (neo)liberal ideologies which typically equated mobility with the values of freedom and universalism (Adey 2017). The unrestricted cross-border movement of labour has been portrayed as one of the central mechanisms promoting intra-EU economic and social integration. The formation of the EU's common labour market was seen as a means to increase productivity, which would subsequently lead to an improvement in living conditions and working standards in the whole region (Verschueren 2015) and, in this, way enhance social cohesion across the member states (Engbersen et al. 2017). Therefore, the mobility of workers has been actively promoted, encouraged and enabled on many levels of EU policy. The European Job Mobility Portal (EURES) was launched to help to disseminate information about job vacancies and connect job-seekers with employers in different EU states, as well as to assist with work placements. In a way, crossborder work-related mobility became part of job activation measures, because unemployed individuals are often advised to move abroad and follow employment opportunities in other member states. Moreover, the EU operates various programmes to stimulate people's mobility, such as the exchange of students, academic staff, artists and specialists.

Simultaneously, one important objective of the EU policy has been to diminish possible impediments to the free cross-border mobility of EU citizens. Since an inability to move acquired social entitlements earned in one EU member state to another could prevent individuals from undertaking work in another EU/EEA country, the European Union Benefits Scheme was implemented to guarantee the transfer of social-security rights between member states (d'Addio and Cavalleri 2015). This portability of social-security rights - albeit to different degrees - applies, for example, to health-care services, old-age and disability pensions, parental leave payments as well as unemployment benefits. In the case of unemployment benefits, the scheme is based on two key principles: the aggregation principle and the exportability principle (Alcidi et al. 2017). The aggregation principle ensures that time worked in any of the member states will be counted when granting access to 
social-security entitlements. The exportability principle allows for acquired rights to social security to be moved from one nation state to another within the EU. This is an important step towards improving social protection accessibility for EU (and EEA) citizens. However, the impact of the EU Benefits Scheme on mobility might be slightly different from that intended due to considerable discrepancies between member states in the scope and capacity of formal social protection. Firstly, as d'Addio and Cavalleri (2015) showed, the EU Benefits Scheme plays a minor role when people make decisions about searching for employment in another EU/EEA state. Secondly, as they further pointed out, it may even have a negative impact if it involves movement from a more-protective to a less-protective welfare environment. Additionally, it may discourage the return migration of unemployed migrants coming from countries with relatively weaker economies and insecure labour markets, as we discuss further in this chapter.

EU enlargement and the common labour market have undoubtedly contributed to the major growth in contemporary intra-EU mobility. According to the annual report of the European Commission, based on Eurostat population statistics, in 2017 there were 17 million EU-28 movers in the EU, of whom 12.4 million were in the working-age group of 20-64 years (Fries-Tersch et al. 2018). The report further indicates that the stocks of EU-28 movers are heavily concentrated in a handful of member states, with Germany, the United Kingdom, Italy, France and Spain hosting $74 \%$ of all movers. At the same time, Romanian, Polish, Portuguese, Italian and Bulgarian nationals made up to more than half of all EU-28 movers. Clearly, the labour demand in West European countries, combined with the continued wage and living condition disparities between Central, Eastern and parts of Southern Europe on the one hand and Western and Northern Europe on the other, drives a large part of intra-European migration. This further indicates that, for many Eastern European citizens, migration can be a strategy to cope with labour-market deficiencies in their home countries, rather than stemming from a desire to live abroad. In this sense, migration is a way to broaden migrants' resource environment beyond a single nation state. A transnational way of living helps individuals to deal with social risks in the home country and secure socio-economic welfare needs for themselves and their families, now and in the future (Levitt et al. 2017). Significantly, since many East European migrants are concentrated in the low-wage service sector of Western European markets, freedom of mobility, instead of reducing social inequalities, may instead reproduce them even further (Engbersen et al. 2017).

Classical economic theories commonly assume an adjustment capacity of migration flows based on the expectation that, in general, workers will follow available job opportunities (Kahanec et al. 2016). Accordingly, it is anticipated that migrants will respond to economic recession in the countries where they are working by moving either back to their countries of origin or onward to countries with better economic prospects. These expectations, however, have often proved misleading or have not been confirmed empirically. Building on examples from six European countries that were intensively recruiting workers in the post-war period to stimulate economic growth, Stephen Castles (1986) showed that what was originally intended as a temporary guest-worker system eventually led to family reunification 
and permanent settlement. Similarly, the recent global recession did not result in mass return migration, partly due to the global character of the recession and the adverse economic and employment situation in the countries of origin (Awad 2009; Castles and Vezzoli 2009). Yet, staying in the host country might not always be possible, especially if migrants are deprived of social assistance or if their legal residence depends on their employment. If they are not ready to change to clandestine residence, they may be compelled to leave the country in the event of losing their jobs.

The current discourse of mobility as desirable and a privilege tends to overlook the fact that many people around the world might prefer to pursue more settled lives. The results of a large cross-country survey demonstrate that only $14 \%$ of the world's adult population wish to migrate to another country (Esipova et al. 2011). Additionally, as Diana Mata-Codesal $(2015,2275)$ argued 'staying put is not a passive-by-default situation' - on the contrary - it may be a valuable asset and a desirable choice for some households, depending on their access to socio-economic resources. However, with the grand narratives of modern times being characterised by fluidity and mobility, the social sciences have tended to normalise movement, simultaneously casting immobility as predominantly involuntary and enforced (Schewel 2019). Kerilyn Schewel (2019) argued instead for an aspiration/capability framework in migration studies, which allows a more comprehensive approach to (im)mobility. As there are many reasons why people move, there are also multiple reasons why people choose to be sedentary. Modifying Carling's (2002) aspiration/ ability model by applying it to a concept of capability, Schewel (2019) suggests that we should look separately at individuals' aspirations and capabilities not only to explain mobility but also to highlight why people do not undertake internal or crossborder migration and also - as we do in this chapter - to explain why some migrants decide to stay or even settle in the destination countries.

Although perceived as voluntary, labour migration is often impelled by confined possibilities in the country of origin. At the same time, patterns of mobility, its length and character, typically depend on migration policies and formal impediments to movement or settlement. For instance, circular migration, the back-andforth travelling that predominated among Polish migrants in the aftermath of the systemic change in Poland, were often conditioned by restricted access to labour markets in Western European countries and the limited possibilities of acquiring legal residency there (Okólski 2001). Therefore, EU enlargement and alleviated residential constraints for EU citizens moving within the EU (EAA) area opened up new prospects for Polish citizens, as they now had more freedom to leave, to stay and to return, depending on their aspirations and available options. Researchers studying post-accession migration from Poland have observed that, despite being intended as temporary, staying in another country often turns out to be prolonged or even permanent (Drinkwater and Garapich 2015). Likewise, the EU Benefit Scheme may encourage and/or facilitate migrants' settlement, as we show in the case of Polish migrants in Iceland.

Generally, EU policy seems to encourage more temporary forms of labour mobility, despite resulting in the growing vulnerability of migrant workers' rights. 
Since employment protection remains, to a great extent, a matter for member states, it generates unfair competition between workers and leads to social dumping (Verschueren 2015). For example, the posting of workers, which falls under the mobility of services, undermines migrants' residential rights and access to welfare systems in the host countries. At the same time, as Verschueren (2015) has demonstrated by taking examples from recent cases brought to the EU Court of Justice, the current trend in EU practice is to favour freedom of commerce, even at the cost of workers' security. Therefore, migrants' mobility and flexibility may be largely framed by EU and member states' policies on the one hand and employers' recruitment practices on the other. It may be imagined, desired and imposed by neoliberal governance rather than being a desired condition by many foreign workers. Labour migration is predominantly driven by employers' need for cheap and supplementary labour in times of increased productivity - labour which can be easily disposed of during economic stagnation or downturn. Hence, migrants tend to be at greater risk of layoff and expulsion, which only perpetuates their temporary status.

This image of the flexible and temporary nature of migrants' work informs and further reinforces social boundaries that deem migrants as not belonging, thereby limiting their access to welfare services - which are traditionally distributed on the basis of national membership and fashioned to respond to the needs of sedentary populations (Anderson and Hughes 2015; Righard 2008). This assumed and implicit equation of migrants with temporary labour is also revealed in some academic discourse which regards migrants' attempts to exercise their rights to social security on levels equal to those of the local population as 'welfare shopping' or 'welfare tourism' (see the introduction to this volume).

\subsection{Methods}

The chapter draws on data from ethnographic research on the position of immigrants in Iceland, data which both authors have been collecting for over a decade and which have focused on employment-related migration to Iceland. However most of the data analysed in this article come from the project 'The participation of immigrants in civil society and labour market in the economic recession', carried out in 2011, about 3 years after the outbreak of the economic recession in Iceland in the autumn of 2008 (see Wojtyńska et al. 2011). The project applied both quantitative and qualitative methods, which included an internet survey among registered unemployed foreign citizens on the one hand and interviews with foreign citizens and representatives of various service-providers on the other. The survey, which was conducted online and sent to all registered unemployed migrants, rendered 516 responses, which was a sizable sample given that, at the time, there were about 1860 foreign citizens registered as unemployed in Iceland. More than half of the answers came from Polish citizens, followed by Lithuanians (12\%) and Latvians (3\%). The interviews were conducted both in two focus groups and individually. One focus group consisted of Polish migrants only and was conducted in the Polish language. 
Another consisted of individuals of different nationalities of whom the majority came from Lithuania and the interviews were conducted in English. Altogether a group of 15 immigrants were interviewed, 11 men and four women. Almost all the men interviewed had worked in construction before losing their jobs, while the women had been employed as cleaners or in low-income service jobs. In this chapter, we focus primarily on the narratives of Polish migrants from the interviews, occasionally supporting our arguments with data from the survey.

\subsection{The Financial Crisis, Unemployment and (Im)Mobility Patterns Among Polish Migrants in Iceland}

Until recently, immigration to Iceland was relatively low and immigrants did not exceed 2\% of the total population until 1998 (Statistics Iceland n.d.-b). A process of privatisation and deregulation of the economy in the early 1990s brought brisk economic growth, seen particularly in the major expansion of the construction industry in the early 2000s. This created substantial shortages of workers on the labour market and led to increased immigration to the country (Skaptadóttir 2011). Besides construction, foreigners were employed mostly in low-income jobs in the service sector, such as cleaning, shop assistance and less-skilled jobs in health care - for instance caring for the elderly in nursing homes. Many were employed in manufacturing, particularly in food production. Consequently, in January 2008, immigrants accounted for $9 \%$ of the total population and constituted a tenth of the Icelandic labour force. Polish migrants were by far the largest migrant group - or about $40 \%$ of all immigrants registered in Iceland in 2008 - making up 3\% of the total Icelandic population (Statistics Iceland n.d.-b). At the time, the unemployment rates among Polish citizens were negligible and, on average, lower than those of the overall population. In the aftermath of the financial crisis of 2008, this changed considerably, when unemployment rates reached $18 \%$ among Poles in 2009, twice as high as the rate for Icelandic citizens (8.2\%) (Directorate of Labour n.d.). The sudden contraction of the economy following the financial crash slowed down immigration to Iceland and a number of Polish workers who had lost their jobs left the country, either returning to Poland or moving to other countries - for example to Norway where they hoped to find new employment. In 2009, for the first time since 1992, net migration between Poland and Iceland was negative (-1583 persons), with more men than women leaving the country (Statistic Iceland n.d.-b). The scale of the outflow could, however, have been larger, since the official statistics include only those persons who were officially registered as residing in Iceland but omit those who have a so-called temporary personal ID number (utanpjóðskráar kennitala), which applied to a number of posted workers. Yet although many Poles left the country, their emigration and that of other foreign citizens was not as extensive as anticipated by the general public or as presented in the media at the time. 
There were many reasons, including non-economic motives, which influenced the decisions of foreign citizens who became unemployed in the aftermath of the financial crisis to stay in Iceland (Skaptadóttir 2014; Pórarinsdóttir et al. 2009; Wojtyńska and Zielińska 2010). For instance, some had already settled in Iceland, brought their families with them or entered relationship with Icelandic citizens. However, even those who saw their migration as temporary tended to evaluate their options, based not only on the situation in Iceland but also on their prospects in Poland. In their analysis of post-crisis mobility patterns among Polish migrants, Janicka and Kaczmarczyk (2016) conclude that the considerable income disparities between Poland and Western European countries still encourage outward population flows from Poland and can deter return migration (with average monthly salaries in Poland amounting to about half of those in Germany or the United Kingdom). Measured by GDP, Poland is usually presented as one of the countries not affected by the global economic recession in 2008. However, as argued by Maciejewska et al. (2016), the crisis in Poland had a 'silent and crawling' character. In response to the global financial crisis, Polish policymakers focused on expanding the flexibility of employment in order to continue attracting foreign investment and maintaining economic growth. Thus, the measures taken by the government to prevent a recession did, in fact, put downward pressure on wages, social security and the labour market and promoting, instead, insecure and precarious employment. Moreover, the unemployment rate in Poland increased to $13.4 \%$ in 2012 and even reached 20\% in some regions (GUS 2014; Wojnar 2012).

Consequently, the reasons that pushed many Poles away from their home country became even more acute during the recession, thus significantly restraining return migration. Many of the Poles we interviewed in Reykjavik doubted whether they could get any job at all, let alone a job which they would find acceptable and which would allow them to meet their needs. Moreover, many believed that the situation in Iceland would soon improve, while often expressing great scepticism regarding the situation in their home country and frequently indicating that there is a "permanent crisis in Poland'. Therefore, even though they had lost their jobs, they felt more economically secure in Iceland, especially if they were eligible for welfareprotection benefits.

Since Iceland opened its labour market to citizens of the new EU member states in May 2006, the migration of Poles to Iceland has been regulated by general EU rules governing the intra-EU mobility of labour, including its social-protection schemes. Polish citizens who have been granted legal residency are incorporated into the Icelandic welfare system after a 6 month stay in the country. Their unemployment rights are, however, linked with their membership in labour unions. After 12 months of full-time employment, they earn the right to full unemployment benefits. However, a person is already entitled to partial benefits after working in Iceland for a minimum 3 months in an at least a quarter-time position.

Although the capacity of the Icelandic welfare scheme is more limited than those in the other Nordic countries (Ólafsson 2005), it can still be described as generous compared to that in countries like Poland. Moreover, during the financial crisis, growing unemployment was recognised as one of the central issues to be addressed. 
In response to the crisis of 2008, rights to unemployment benefits in Iceland were extended, first to three years and then to four years in 2010. After 1 January 2015, unemployment benefits were shortened to two and a half years or 30 months. For the first 3 months, benefits are wage-related and calculated as $70 \%$ of the average income based on the 6-month period ending 2 months before a person becomes unemployed (Directorate of Labour n.d.). After 3 months, unemployed individuals are paid a flat amount in basic benefits. In 2011, when the interviews on which this discussion builds were conducted, the basic benefits were about ISK 160,000 (EUR 973), amounting to $52 \%$ of the median salary in Iceland at that time. The benefits are about ISK 280,000 (EUR 2032), which corresponded to about $70 \%$ of the median salary in 2018 (own elaboration based on Statistics Iceland n.d.-a).

In comparison, in the past decade, Poland offered six to 12 months (180-365 days) of unemployment benefits (Pątek 2017). In 2011, the amount of unemployment benefits during the first 3 months equalled $22 \%$ of the average gross salary and $18 \%$ in the following months (own calculations based on GUS 2014). In 2018, the benefits were PLN 847.8 (EUR 197) for the first 3 months (17\% of the average gross salary) and PLN 665.7 (EUR 154) in the following months (14\% of the average gross salary). Based on EU regulations, immigrants can move their acquired rights between member states. However, Poles are eligible to receive benefits at the Icelandic level for only three consecutive months, after which they are subject to Polish unemployment arrangements. Thus, moving unemployment benefits from Iceland to Poland would clearly compromise the household income and economic situation of Polish migrants and their families to a considerable extent. At the same time, their employment possibilities in Poland, like those that motivated their emigration in the first place, would remain limited.

Finding work in Poland would not necessarily secure an adequate financial situation, as aptly illustrated by the case of Krystyna (pseudonym), a middle-aged Polish woman, whom we interviewed in 2010 in Iceland. When she lost her job there at the beginning of the economic recession, she decided to return to Poland. She took a manual job in a small factory in her native town, where she said she was paid PLN 5 per hour (about EUR 1.5 at that time). In an interview, Krystyna recalled the moment when she received her first salary for this job. She said it had felt like being on the edge of a nervous breakdown, concluding: 'I cannot keep working for so little money'. She quit her job in Poland and went to Sweden for 2 months where she earned money picking berries. 'It was only a summer job, but one needs to live somehow', she said, explaining her decision to move from Sweden back to Iceland. After she returned to Iceland, she worked for 3 months before becoming unemployed again. However, this time she chose to stay in Iceland and use her right to unemployment benefits.

Typically, migration has been applied as a strategy to compensate for the deficiencies of the local labour market and its capacity to provide enough income to secure the welfare of the household. Many Poles used the wages earned in Iceland to provide for families who lived in Poland. While earlier studies on Polish migration showed that remittances were chiefly used for everyday expenses and to cover unexpected additional costs like house renovation (Kaczmarczyk 2004), they were 
also used to meet other inadequacies of the Polish social-welfare system - in particular, old-age pensions or access to higher education. Some of our informants mentioned that they wished to work in Iceland to secure their retirement benefits or to support their elderly parents (cf. Krzyżowski and Mucha 2014). Another recurrent topic in the interviews was the need to finance children's education - almost half of all university students in Poland need to pay for their education (Natalli 2015). In 2013, the average university fee was around PLN 8100 (EUR 1955) per academic year. Based on the data from a survey among fifth-year students in the Economics Department of Szczecin University, Wojciech Jarecki (2012) concluded that a considerable portion of students' budgets comes from parents. Since not all parents are able to support children with the salaries they earn in Poland, some choose to seek higher wages abroad.

The need to facilitate the education of his children was very prominent in the narrative of Stanisław, a man in his 50s, who had been working for a year in the Icelandic construction sector before he became unemployed. At the time of the interview, he was actively looking for a job but, because the financial crisis had resulted in contraction in the building industry, there were no openings in his field. As Stanisław explained, he had come to Iceland mainly because he wanted to earn money for his daughters' education. He said, 'I don't know if it will secure a job for them in the future, but it is better to sweep floors with a diploma than without one'. Although he did not intend to settle in Iceland, he concluded 'I came here with a very specific purpose - to educate my children - and I will stay here until I reach my goal'. He elaborated on his decision to stay in Iceland despite the economic recession in the following way:

To be honest, I now consider Iceland my second fatherland, because it gave me what Poland did not give me. (...). A good life for me and my family. I mean a normal life, because this is not about abundance but about earning enough to last from the first to the last day of the month; for the basics - food, a flat and the education of my children. (...). [After the crisis], it is worse here. The prices rise, inflation is very high. But still, there are normal relations. I can even save about 400-500 euros per month. This is money I would never earn working in the town I come from. (...). I would like to go back, but I am terrified that then my children would not be able to study.

Given that peoples' decision to move from Poland to Iceland was commonly motivated by a need to improve their or their families' financial situation (the overall welfare of the family remaining in Poland), staying on benefits could still help them to meet this goal and fulfil their financial and care responsibilities towards the family. The cases of Krystyna and Stanisław demonstrate that many of the Polish migrants who became unemployed still felt financially more secure in Iceland than they would be by returning to Poland. Ironically enough, because migration was mostly driven by the availability of jobs in the low-wage sector of the Icelandic economy and many migrants were paid at or below the minimum-wage level (Friberg et al. 2013), they did not experience a major deterioration in their monthly income after transferring to unemployment benefits.

Interestingly, the financial security that Stanisław equated with the ability to lead a 'normal life' (Dzenovska 2014) engenders a sense of belonging that makes him 
call Iceland his second fatherland. Although he wished to return to Poland at some point, as he mentioned in the interview, he expressed his disappointment at his native country apparently failing to fulfil its duty to ensure decent survival. This also shows that attachments are built not only on the basis of social and cultural affinity but also on a sense of security - being able to provide for oneself and one's family or to fulfil one's aspirations for a good ('normal') life.

The financial crisis, combined with the Icelandic social-protection environment, had certain implications for the mobility patterns of Polish migrants. As already mentioned, many of them, especially single men, left the country during the recession but others still considered the situation in Iceland more favourable than the one they could expect back in Poland. Losing a job and having fewer job opportunities did not simply mean return migration - it even, to some extent, seems to have underpinned family reunification and hence more settled migration. The sudden and sizable decrease in the value of the Icelandic króna against the Polish złoty (and the euro) affected the value of migrants' savings and the remittances they were sending to Poland. A survey, conducted in 2010, showed that $30 \%$ of the unemployed respondents were living in divided households and that $38 \%$ reported sending money to their country of origin (Wojtyńska 2012). This was a considerably lower percentage compared to findings from a survey of remittances conducted right before the crisis (in 2008), when 56\% of respondents were engaged in this practice (Jónsdóttir et al. 2009). One reason for the smaller number of people making transfers to Poland is the reunification of families following the financial crisis; another explanation is the inability to save enough money to send to Poland, which was mentioned by $39 \%$ of the unemployed respondents in the above-mentioned study. Consequently, some of the Polish migrants we interviewed explained that, with the lower value of the wages earned in Iceland, it was too expensive for them to maintain two households and continue a transnational way of life, so they brought their families to Iceland.

\subsection{Mobile Workers Facing the National Logic of Welfare Regimes}

Engbersen et al. $(2017,344)$ argue that 'the heterogeneity and diverse temporalities of intra-EU mobility set new challenges for the European destination regions and cities'. Many Polish migrants are undecided about their future, adjusting their strategies and mobility-versus-settlement patterns in response to the changing economic situation and the available resources in the sending and receiving countries. While living in Iceland, many maintain social linkages with and care responsibilities towards family - frequently children or aging parents - and/or relatives who stay in Poland, as we described in the section above. Even if they were unemployed, some migrants had a better likelihood of meeting these responsibilities if they remained in Iceland. At the same time, state welfare policies, which are largely organised 
according to national and sedentary logic, do not accommodate this transnational nature of migrant lives (Righard 2008). National ideology informs not only formal eligibility rules but also the practices and attitudes of the welfare-service personnel responsible for allocating both state- and third-sector-provided services.

Increasingly, the internationalised labour market, including intra-EU labour mobility, typically entails the formation of transnational social fields that span multiple nation states. This means that the living realities of transnational migrants typically cross national borders. Being socially embedded in different localities, migrants engage in back and forth travelling, regularly visiting their families or relatives living in Poland. Although part of their free time, visits are primarily undertaken in response to family and care obligations, which might be even more acute in cases where there are divided households (Wojtyńska and Skaptadóttir 2020). However, the rules regarding eligibility for unemployment benefits in Iceland may require modification of the mobility practices common among migrants prior to the crisis. A person registered as unemployed is generally defined as someone who is active in the labour force and, as such, is actively searching for work and available to accept any job offers presented by the authorities. However, job-seeking intrinsically implies looking for work in Iceland. The unemployed person must also be ready to participate in various meetings, courses and activation programmes sponsored by the Icelandic Directorate of Labour, which requires that the person is present in Iceland when the employment office contacts him or her.

The employment office utilises different methods to control whether or not a person meets these obligations. Job-seekers need to 'report' monthly to the Icelandic Directorate of Labour. This reporting can be done on-line but it must be done in Iceland and the Directorate of Labour checks IP numbers to trace the location of the computer the job-seeker uses to register. This of course does not mean that people cannot travel abroad while unemployed but that they are required to notify the office whenever they intend to leave Iceland; this period is then categorised as holiday and reduces the amount of benefits. If people do not report their travel or are discovered reporting from abroad, they risk losing their unemployment benefits - as a result, migrants may be constrained from visiting their families in Poland to avoid this happening.

These rules apply equally to Icelandic and foreign citizens. Nevertheless, they conflict with the nature of transnational living pursued by many migrants by reducing a migrant's visits home for solely leisure activities and penalise each trip to Poland in some way. Moreover, foreign citizens are apparently subjected to additional scrutiny, precisely because of their transnational practices and the greater likelihood of travel abroad. As one employee of the Icelandic Directorate of Labour told us in an interview: 'We contact people at a short notice to make sure they stay in Iceland. We don't want to sponsor holidays in Poland for them'. Consequently, unemployed foreign citizens registered with the office are occasionally called in for sudden and unexpected checks, as Ola, one of our informants in her 30s, explained:

I remember, I once got a notification. I had just registered that I was going on holiday from unemployment, since I was going to Poland. I had holidays from the $9^{\text {th }}$ [of the month], and on the $5^{\text {th }}$ [same month] I had to come to the office, just [a few days] before my flight. I got this message at 8 o'clock in the evening of the day [before] they wanted me to come; I had to come at $1 \mathrm{pm}$ the next day. 
Due to their EU citizenship, Polish migrants are entitled to Icelandic publicwelfare services but they still encounter various social boundaries when seeking formal assistance. Robert, another of our participants, cited his experience of irregular and often hostile attitudes on the part of office workers at the Directorate of Labour. Robert lost his job in a bakery right before completing the 3 years' employment that would have allowed him to turn his temporary contract into a permanent one. He complained that he felt information had been repeatedly withheld from him and that he had been misinformed about regulations or changes in the rules regarding unemployment arrangements; this had ultimately put his eligibility at risk (it cost him his right to benefits). In general, an unemployed person has the right to combine paid work with unemployment benefits but he needs to notify the Directorate of Labour so that the amount of benefits can be reduced proportionally. According to the information which Robert received at the initial meeting with the Directorate of Labour, it was alright to notify the office afterwards. However, when he delivered his payslip regarding the additional work he had undertaken, it turned out that he should have done so before the work was performed. He concluded:

I don't understand this, why they never tell us when they implement some new rules. (...). I am not sure, but maybe they just wait until you make a mistake and lose benefits. Then they are happy to have one less person to support. It is true. They just treat us [foreign workers] as a commodity.

Robert also felt that he does not receive enough assistance from the office when looking for work, being treated differently to - in his opinion - the Icelandic unemployed who, he claims, are more likely to receive alerts about new job openings.

We observed similar resentment among some of the charity workers whom we interviewed in our research. There are various third-sector organisations that provide food and other assistance for people in need and many unemployed Poles were told to seek help from them in the aftermath of the financial crisis. Since Poles were often informed about this assistance at the Directorate of Labour office, many considered this part of the state provision for the unemployed. Not all migrants had worked long enough in Iceland to earn the right to full benefits and, with reduced payments, some faced considerable financial hardship. The sudden increase in foreign citizens among the clients of charities was met with scepticism by some charity workers, as illustrated by the following quote:

Yes, after the crisis, these people began to be visible already in 2008 and it was men... men who were imported, literally - and that is a problem. There are many problems resulting from this because they have lower wages than Icelandic men.

In the eyes of many charity workers, migrants were often reduced to the status of temporary labourer and their low wages were seen more as a 'problem' than as an explanation for why they might be seeking help. Although there are no formal criteria for clients to receive assistance, some charities began asking Polish citizens to present confirmation of their registration as unemployed with the Directorate of Labour (ironically reinforcing migrants' idea that charities were part of the services for the unemployed). One charity introduced different waiting lines for Icelandic and foreign citizens. These new forms of scrutiny were clearly designed to control 
and restrict access to their services. The distrust on the part of charity workers, who often did not see migrants as rightful clients, clearly reflects existing social boundaries that define migrants as less than full members of Icelandic society (cf. Rice and Wojtyńska 2018).

The attitudes of service workers towards unemployed foreign citizens - both as revealed in our interviews and as perceived by the Polish migrants themselves clearly indicated that there were certain ideas about deservingness. The rhetoric of eligibility is based less on formal membership of a group and more on a subjective notion of someone belonging to a 'community of value', one 'comprised of people who share common ideas and (exemplary) patterns of behaviour expressed through ethnicity, religion, culture or language' (Anderson and Hughes 2015, 2). It would seem that the prevailing image of migrants as mainly temporary labour defines them as not fully belonging to Icelandic society and thus not entirely deserving of social assistance unless they demonstrate a readiness to integrate.

Likewise, the nation-centred logic informs a large share of the activation programmes and courses offered by the Directorate of Labour, services which are mainly focused on improving Icelandic language skills and knowledge of Icelandic society. Hence, they focus on integrating migrants into Icelandic society as measures to help them to find employment. While intended to improve migrants' employment possibilities by making migrants fit the demands of the Icelandic labour market, such activation programmes indirectly instigate migrants' permanent settlement. This again shows how the organisation of a national welfare system tends to be at odds with migrants' mobile practices, the intra-European labour mobility regime and the neoliberal demand for flexible labour (Righard 2008). Moreover, Icelandic courses - even if undoubtedly helpful for those willing to improve their language skills - can also be perceived as another way to 'discipline' the foreign unemployed. They are obligatory and, if a person misses class, benefits are suspended until the absence is explained. If the absence is not explained, the benefits are deducted.

\subsection{Conclusion}

The growing demand for migrant workers within the intra-European common market under neoliberal governance fosters a greater cross-border mobility of people, resulting in individual living realities stretching across different nation states. While work abroad provides opportunities for socio-economic betterment, transnational households typically emerge in response to low-wage and insecure employment in the destination countries. Many migrants conceive of their work abroad as a temporary strategy - this imagined temporality is often reinforced by employers' recruitment strategies, migration policies and social boundaries that often deem migrants as not belonging. Conversely, as the last financial crisis showed in the case of Polish migrants in Iceland, people adjust their mobility and settlement patterns in response to social risks in their countries of origin, as well as conditions in the countries of 
destination, in that way negotiating between aspirations and available opportunities (Schewel 2019). Despite losing their jobs, many of the unemployed Polish migrants still found better social protection for themselves and their families in Iceland compared to what they could expect if they had chosen to return to Poland. Given their EU membership, immobility rather than return migration gave them access to a combination of state and third-sector social-support arrangements in Iceland. This shows that, counter to its initial intention, the EU Benefit Scheme may contribute to a more permanent stay, especially in the context of migration from less- to moregenerous welfare states. However, this is not the only contradiction inherent in contemporary labour migration.

Our study also demonstrated an ambiguous relationship between migrants' alleged temporality - which was largely framed by employers' recruitment strategies - and migrants' actual practice, which resulted from efforts to fulfil their welfare responsibilities. Furthermore, there is an apparent tension between a transnational way of living (whether desired or enforced) and the national logic of welfare provision in member states. Organised by ideas of sedentariness, national membership and social cohesion, welfare states take little account of the transnational character of migrants' lives. This is revealed on many levels, for instance in formal eligibility rules and in institutional practices and attitudes on the part of social-welfare-service personnel, all of which may hinder access to social protection. It also becomes apparent in the rhetoric of deservingness, where foreign citizens and mobile individuals (because of their assumed temporality) tend to be disregarded as legitimate beneficiaries of support.

Acknowledgement This chapter is a contribution to the project "Inclusive societies? The integration of immigrants in Iceland (Grant number: 184903-051)". Authors would also like to thank "Mobilities and Transnational Iceland" project (Grant number: 163350_053) for supporting their participation in the book-related workshop in Malmö in June 2019 as well as proofreading of the chapter.

\section{References}

Adey, P. (2017). Mobility. London: Routledge.

Alcidi, C., Barslund, M., Busse, M., Ludolph, L., Nicoli, F., \& Thirion, G. (2017). Additional effects of a European unemployment benefit scheme. Brussels: European Commission, CEPS Special Report.

Anderson, B., \& Hughes, V. (2015). Citizenship and its others. London: Palgrave Macmillan.

Awad, I. (2009). The global economic crisis and migrant workers: Impact and response. Geneva: International Labour Organization.

Carling, J. (2002). Migration in the age of involuntary immobility: Theoretical reflections and Cape Verdean experiences. Journal of Ethnic and Migration Studies, 28(1), 5-42.

Castles, S. (1986). The guest-worker in Western Europe: An obituary. International Migration Review, 20(4), 761-778.

Castles, S., \& Vezzoli, S. (2009). The global economic crisis and migration: Temporary interruption or structural change? Paradigmes, 2, 68-75. 
d'Addio, A. C., \& Cavalleri, M. C. (2015). Labour mobility and the portability of social rights in the EU. CESifo Economic Studies, 61(2), 346-376.

Directorate of Labour. (n.d.). Talnaefni um atvinnupátttöku og atvinnuleysi erlendra ríkisborgara 2006-2014. Reykjavik: Directorate of Labour.

Drinkwater, S., \& Garapich, M. P. (2015). Migration strategies of polish migrants: Do they have any at all? Journal of Ethnic and Migration Studies, 41(12), 1909-1931.

Dzenovska, D. (2014). Bordering encounters, sociality and distribution of the ability to live a "normal life'. Social Anthropology, 22(3), 271-287.

Engbersen, G., Leerkes, A., Scholten, P., \& Snel, E. (2017). The intra-EU mobility regime: Differentiation, stratification and contradictions. Migration Studies, 5(3), 337-355.

Esipova, N., Ray, J., \& Pugliese, A. (2011). Gallup world poll: The many faces of migration. Based on research in more than 150 countries. Geneva: International Organization for Migration in cooperation with GALLUP.

Eydal, G. B., \& Ottósdóttir, G. (2009). Immigration and the economic crisis: The case of Iceland (Working paper no. 4). Reykjavik: Pjóðmálastofnun Háskóla Íslands.

Friberg, J. H., Arnholtz, J., Eldring, L., Hansen, N. W., \& Thorarins, F. (2013). Labour market regulation, migrant workers and varieties of 'social dumping' in Oslo, Copenhagen and Reykjavik. In J. H. Friberg \& L. Eldring (Eds.), Labour migrants from Central and Eastern Europe in the Nordic countries: Patterns of migration, working conditions and recruitment practices (pp. 43-88). Copenhagen: Nordic Council of Ministers.

Fries-Tersch, E., Tugran, T., \& Bradley, H. (2018). 2017 annual report on intra-EU labour mobility. Brussels: European Commission.

Garðarsdóttir, Ó. (2012). Fólksflutningar til og frá Íslandi 1961-2011 með áherslu á flutninga á samdráttarskeiðum. Reykjavík: Ministry of Welfare.

GUS. (2014). Registered unemployment II quarter 2014. Warsaw: Główny Urząd Statystyczny.

Janicka, A., \& Kaczmarczyk, P. (2016). Mobilities in the crisis and post-crisis times: Migration strategies of poles on the EU labour market. Journal of Ethnic and Migration Studies, 42(10), $1693-1710$.

Jarecki, W. (2012). Indywidualne koszty studiowania na przykładzie kierunków ekonomicznych w uczelniach szczecińskich [Individual study costs based on the example of economic faculties at Szczecin universities]. Studia Regionalne i Lokalne, 13(50), 96-110.

Jónsdóttir, V., Harðardóttir, K. E., \& Garðarsdóttir, R. B. (2009). Innflytjendur á Íslandi: Viðhorfskönnun. Reykjavik: Social Science Research Institute, University of Iceland.

Kaczmarczyk, P. (2004). Znaczenie migracji sezonowych dla migrantów, ich rodzin i społeczności wysyłających. In P. Kaczmarczyk \& W. Łukowski (Eds.), Polscy pracownicy na rynku Unii Europejskiej. Warsaw: Wydawnictwo Naukowe Scholar.

Kahanec, M., Pytlikova, M., \& Zimmermann, K. F. (2016). The free movement of workers in an enlarged European Union: Institutional underpinnings of economic adjustment. In M. Kahanec \& K. F. Zimmermann (Eds.), Labor migration, EU enlargement, and the great recession (pp. 1-34). Berlin/Heidelberg: Springer.

Krzyżowski, Ł., \& Mucha, J. (2014). Transnational caregiving in turbulent times: Polish migrants in Iceland and their elderly parents in Poland. International Sociology, 29(1), 22-37.

Levitt, P., Viterna, J., Mueller, A., \& Loyd, C. (2017). Transnational social protection: Setting the agenda. Oxford Development Studies, 45(1), 2-19.

Maciejewska, M., Mrozowicki, A., \& Piasna, A. (2016). The silent and crawling crisis: International competition, labour market reforms and precarious jobs in Poland. In M. Myant, S. Theodoropoulou, \& A. Piasna (Eds.), Unemployment, internal devaluation and labour market deregulation in Europe (pp. 229-254). Brussels: ETUI.

Mata-Codesal, D. (2015). Ways of staying put in Ecuador: Social and embodied experiences of mobility-immobility interactions. Journal of Ethnic and Migration Studies, 41(14), 2274-2290.

Natalli, K. (2015). Indywidualne koszty i efekty inwestycji w wyższe wykształcenie [Individual costs and effects of investment in higher education]. Spoteczeństwo i Ekonomia, 4(2), 85-99.

Okólski, M. (2001). Incomplete migration: A new form of mobility in Central and Eastern Europe. The case of Polish and Ukrainian migrants. In C. Wallece \& D. Stola (Eds.), Patterns of migration in Central Europe (pp. 105-128). London: Palgrave Macmillan. 
Ólafsson, S. (2005). Normative foundations of the Icelandic welfare state: On the gradual erosion of citizenship-based welfare rights. In N. Kildal \& S. Kuhnle (Eds.), The normative foundations of the welfare state: The Nordic experience (pp. 214-236). Abingdon: Routledge.

Pątek, A. (2017). Social security in Poland. Warsaw: The Social Insurance Institution (ZUS).

Rice, J. G., \& Wojtyńska, A. (2018). Ambiguous spaces: The charity-NGO nexus in Iceland. Journal of Organizational Ethnography, 8, 82-94.

Righard, E. (2008). The welfare mobility dilemma. Transnational strategies and national structuring at crossroads. Lund: University of Lund, School of Social Work.

Schewel, K. (2019). Understanding immobility: Moving beyond the mobility bias in migration studies. International Migration Review, 54(2), 328-355.

Skaptadóttir, U. D. (2011). The context of Polish immigration and integration in Iceland. In M. Budyta-Budzyńska (Ed.), Integration or assimilation? Polish immigrants in Iceland (pp. 18-28). Warsaw: Scholar.

Skaptadóttir, U. D. (2014). What happened to the migrant workers? In E. P. Durrenberger \& G. Pálsson (Eds.), Gambling debt: Iceland's rise and fall in the global economy (pp. 175-185). Boulder: University Press of Colorado.

Statistics Iceland. (n.d.-a). Wage and income statistics. https://www.statice.is/statistics/society/ wages-and-income/. Accessed 15 Sep 2020.

Statistics Iceland. (n.d.-b). Population statistics. https://www.statice.is/statistics/population/inhabitants/. Accessed 15 Sep 2020.

Pórarinsdóttir, H., Georgsdóttir, S. H., \& Hafsteinsdóttir, B. L. (2009). Staða innflytjenda á erfiðleikatímum: Raddir og viðhorf. Reykjavík: MIRRA - Miðstöð Innflytjendarannsókna ReykjavíkurAkademían.

Verschueren, H. (2015). The European internal market and the competition between workers. European Labour Law Journal, 6(2), 128-151.

Wojnar, J. (2012). Regionalne zróżnicowanie bezrobocia w Polsce w latach 1998-2011 [Regional differentiation of unemployment in Poland in the years 1998-2011]. Nierówności społeczne a wzrost gospodarczy, 24, 404-411.

Wojtyńska, A. (2012). Polish workers in the capital area of Iceland. In S. Eggertsson \& A. G. Ásgeirsdóttir (Eds.), Pjóðarspegillinn: Rannsóknir í félagsvísindum XIII (pp. 1-12). Reykjavik: Social Science Research Institute, University of Iceland.

Wojtyńska, A., \& Skaptadóttir, U. D. (2020). Re-creational travelling: Polish migrants visiting their families in Poland. Emotion, Space and Society, 34(1), 1-7.

Wojtyńska, A., \& Zielińska, M. (2010). Polish migrants in Iceland facing the financial crisis. In G. P. Jóhannesson \& H. Björnsdóttir (Eds.), Rannsóknir í félagsvísindum X (pp. 1-11). Reykjavik: Social Science Research Institute, University of Iceland.

Wojtyńska, A., Skaptadóttir, U. D., \& Ólafs, H. (2011). The participation of immigrants in civil society and labour market. Unpublished report available at http://mark.hi.is/skyrslur. Accessed 15 Sep 2020.

Open Access This chapter is licensed under the terms of the Creative Commons Attribution 4.0 International License (http://creativecommons.org/licenses/by/4.0/), which permits use, sharing, adaptation, distribution and reproduction in any medium or format, as long as you give appropriate credit to the original author(s) and the source, provide a link to the Creative Commons license and indicate if changes were made.

The images or other third party material in this chapter are included in the chapter's Creative Commons license, unless indicated otherwise in a credit line to the material. If material is not included in the chapter's Creative Commons license and your intended use is not permitted by statutory regulation or exceeds the permitted use, you will need to obtain permission directly from the copyright holder.

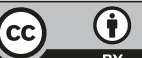

